\title{
Thermal damage to red cells
}

\author{
S. BAAR AND D. J. ARROWSMITH \\ From the Medical Research Council Industrial Injuries and Burns Unit, Birmingham Accident \\ Hospital, and the University of Aston in Birmingham, Gosta Green, Birmingham
}

SYNOPSIS Erythrocytes from a burned patient show a temporal sequence of morphological changes. Immediate severe changes occur which are followed by a transient phase only of less abnormal morphology.

Heating whole blood in vitro to $49^{\circ} \mathrm{C}$ instead of $50^{\circ} \mathrm{C}$ does not show the expected dose response curve.

Heating whole blood in vitro to $50^{\circ} \mathrm{C}$ induces progressive morphological changes.

Fractionation of whole blood and subsequent heating to $48^{\circ} \mathrm{C}$ show the older cells to be less deformable.

Morphological changes induced by heating were first observed over a century ago (Schultze, 1865) when microspherocytosis and fragmentation were noted. Similar gross changes were also noted after burning injuries and reported by Shen, Ham, and Fleming (1943). Severely affected cells were shown to be rapidly eliminated from the patient's circulation and this cell destruction accounted for the rapid appearance of haemoglobinaemia and haemoglobinuria, as already noted by Pfeiffer (1905).

The differing susceptibility of old and young erythrocytes to thermal damage was suggested by the decreased osmotic fragility of the red cells about 36 hours after the injury (Shen et al, 1943) and was confirmed by Kimber and Lander (1964).

Transformation from discs to spheres following thermal damage, the earliest morphological manifestation of heat injury, increases the susceptibility of such cells to lysis by hypotonic saline (Castle and Daland, 1937) and cellular hydration (Baar, 1967).

While the elucidation of the mechanisms responsible for the alteration of red cell morphology immediately after thermal injury is of undoubted importance, a study of possibly reversible stages as may occur in the younger cell population is Received for publication 4 March 1970. of greater immediate importance to the burned patient since such cells may be expected to have a shortened life span. Davies and Topley (1956) have demonstrated an increased rate of disappearance of erythrocytes in burned subjects.

Normal survival of the red cell is dependent upon its normal metabolism which requires a functionally intact cell membrane. A more detailed study of the membranes of heatdamaged erythrocytes promised therefore to yield valuable information on metabolic lesions caused by heat.

The development of the Cambridge Stereoscan scanning electron microscope ${ }^{1}$ offered a tool suitable for such a study. Salsbury and Clarke (1967a) first used this technique to study human red cell surfaces and extended their observations (1967b, 1968) to certain haematological disorders and experimental work.

\section{Materials and Methods}

BLOOD SAMPLES

Blood from one patient was examined. The patient, a child aged 2 years, had suffered burns on about $75 \%$ of the body surface.

'Cambridge Scientific Instruments Ltd. 
The work in vitro was carried out on pooled haematologically normal blood and at least five specimens were pooled. Sequestrene $\left(\mathrm{Na}_{2}\right)$ was used as anticoagulant. Amounts of this blood, each of $0.1 \mathrm{ml}$, were fixed in $2 \mathrm{ml}$ phosphatebuffered glutaraldehyde $(p \mathrm{H} 7.4)$ as described by Lewis (1967).

Amounts of the patient's blood, each of $0.1 \mathrm{ml}$, were directly delivered into the fixative. Fixation was allowed to proceed for $15 \mathrm{hr}$ in the refrigerator. The supernatant was then decanted and the cells were washed twice with $2 \mathrm{ml}$ water. The final suspension was prepared in $1 \mathrm{ml}$ water. Cell preparations for coating were made on glass squares about $1 \mathrm{~cm}^{2}$ by flooding the surface with the cell suspension and subsequently removing most of the liquid with a Pasteur pipette. The residual film was allowed to dry in air (Clarke, personal communication, 1968).

The samples were then vacuum coated with $50 \AA$ of carbon and $50 \AA$ of gold-palladium alloy to render the surface electrically conducting for direct examination of the surface by the Stereoscan scanning electron microscope. The total thickness of the coating, $100 \AA$, was less than the best resolution of the Stereoscan and considerably less than the $600 \AA$ resolution of the instrument as operated for this research. The principles of scanning electron microscopy have been fully described by Oatley, Nixon, and Pease (1965). Its main advantage is that it enables direct examination of surfaces, the image being formed by emission of electrons from the surface instead of by transmission of electrons through the specimen as in conventional transmission electron microscopy. At low magnifications the

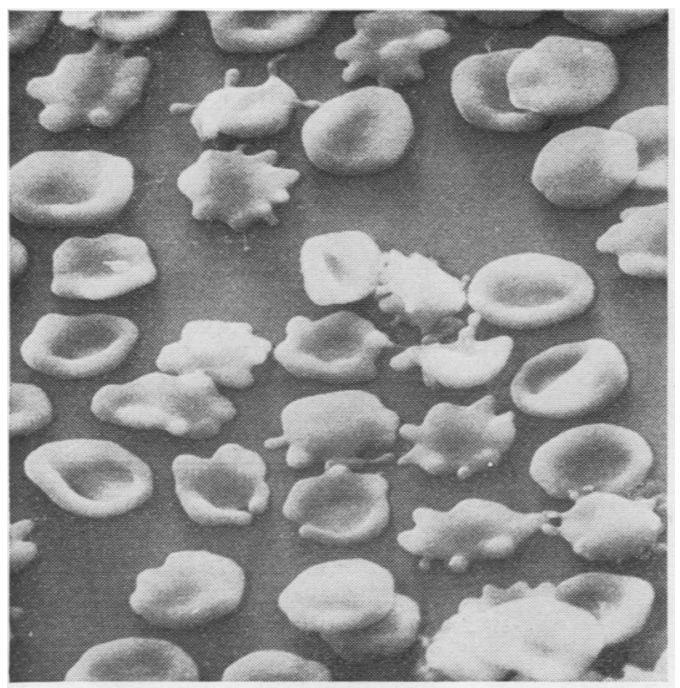

Fig. 1 Venous blood from burn?d patient. Approximately $75 \%$ body surface burn. Two hours after burning. $\times 2,700$. appearance of the image is similar to that observed by optical reflection microscopy only with a depth of focus two to three orders of magnitude better. At all magnifications the 3-D effect assists in visual interpretation. By taking stereo pairs and using a stereometer it is possible to make measurements in three dimensions.

The specimens were examined at a tilt angle of $45^{\circ}$ and at $20 \mathrm{kV}$. Images were recorded photographically on $35 \mathrm{~mm}$ Kodak Tri-X film and enlarged to the original screen size.

\section{HEATING}

Two $\mathrm{ml}$ of whole blood was heated in a shaking water bath for 10 min (90 oscillations per minute) and cooled in iced water. The temperatures used were $48^{\circ} \mathrm{C}, 49^{\circ} \mathrm{C}$, and $50^{\circ} \mathrm{C}$.

\section{FRACTIONATION}

The desired cell populations were prepared by a method based on that developed by Danon and Marikovsky (1964). A mixture of di-methyl phthalate and di-n-butyl phthalate of SG 1.104 was used. Micropolypropylene tubes as available for use in conjunction with the micro rotor head of the Hawksley micro haematocrit centrifuge were almost filled with blood. The blood was then overlaid with 2 drops of the ester mixture and centrifuged for $14 \mathrm{~min}$ at $10,000 \mathrm{~g}$ in a refrigerator to avoid warming. The respective cell populations were obtained by cutting the tubes above and below the ester layer and resuspending the cells to an approximated cel volume of $40 \%$ in their own plasma.

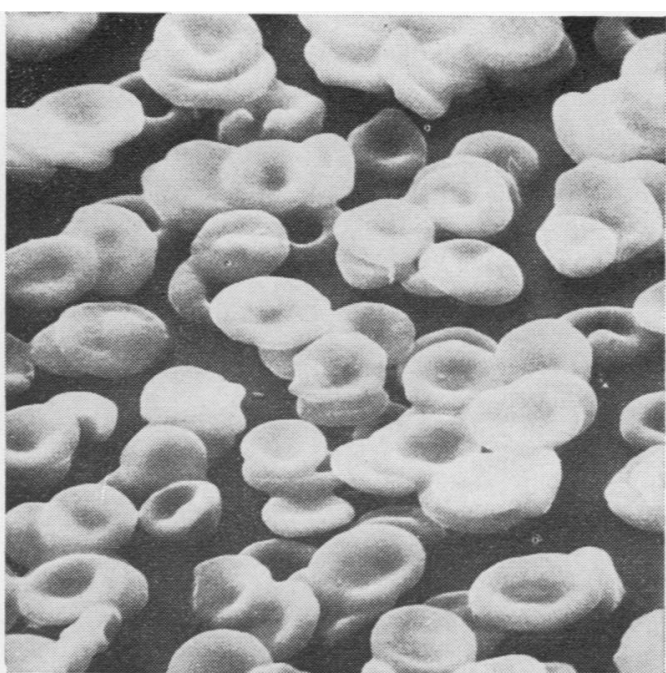

Fig. 2 Venous blood from burned patient. Approximately $75 \%$ body surface burn. One hour before death. $\times 2,660$. 
The percentage fraction was determined in duplicate tubes. The top and bottom layer cells were lysed with $0.4 \%$ ammonia solution and the oxyhaemoglobin content was determined at 540 $\mathrm{nm}$.

\section{Results}

Figure 1 shows the appearance of a venous blood preparation two hours after the injury and before intravenous therapy showing an almost complete absence of normal cells. Fragments, severely crenated, and even cells resembling target cells can be seen. During the next 24 hours $570 \mathrm{ml}$ of whole blood was transfused to this patient. Figure 2 shows a sample of blood

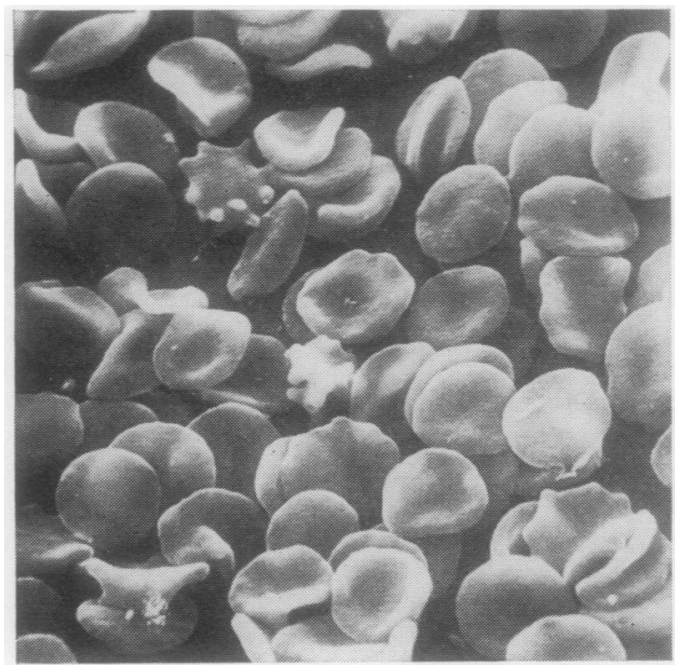

Fig. 3 Whole normal blood heated in vitro for five minutes at $49^{\circ} \mathrm{C} . \times 2,440$.

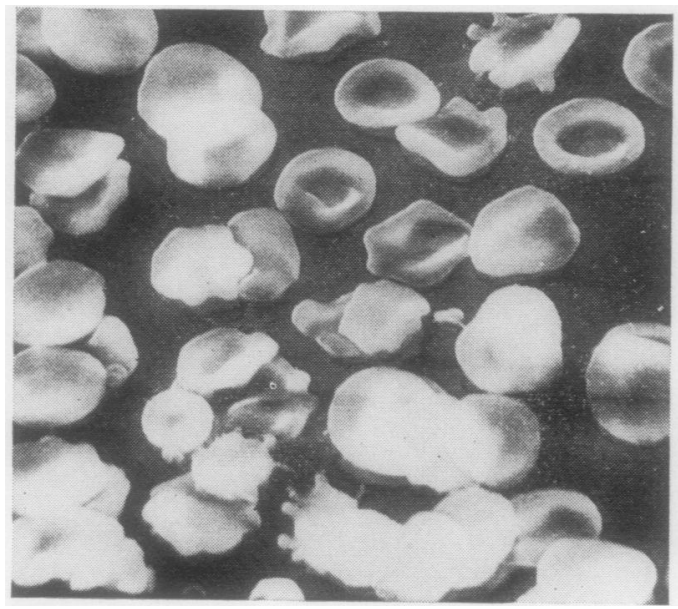

Fig. 5 Whole normal blood heated in vitro for four minutes at $50^{\circ} \mathrm{C} . \times 2,580$. several hours after the transfusion and shortle before death. In spite of the large transfusion many of the cells are highly abnormal. The bizarre shapes evident in Fig. 1 have been replaced $b \bar{\Phi}$ abnormal discoid shapes of subnormal cell diameter and rough texture.

Whole normal blood heated for five minutes at $49^{\circ} \mathrm{C}$ (Fig. 3) shows many cells similar to those seen in Fig. 1-notably a similar roughness of the cell surface. Heating for 10 minutes at th same temperature did not increase the abnormak ity of the cell morphology.

Repetition of a similar experiment at $50^{\circ} \overrightarrow{\mathcal{e}}$ shows a different sequence of events. Three minutes' heating (Fig. 4) produces a similam cell morphology as five minutes' heating to $49^{\circ} \mathrm{C}$. The changes at $50^{\circ} \mathrm{C}$ are, however, prot gressive as illustrated by Figs. 5 and 6, which

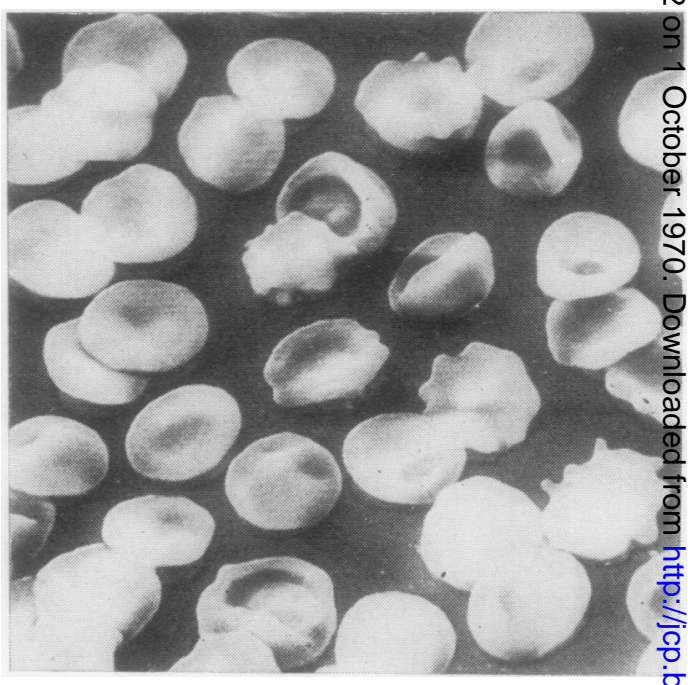

Fig. 4 Whole normal blood heated in vitro for three minutes at $50^{\circ} \mathrm{C} . \times 2,700$.

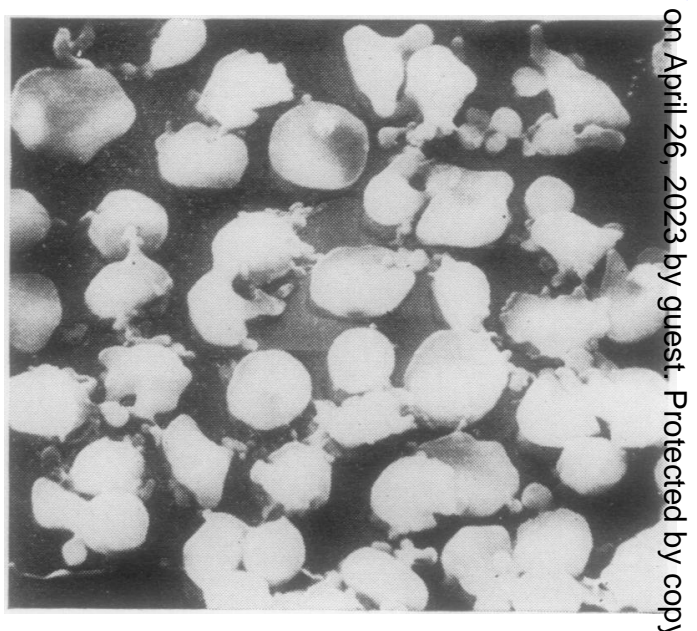

Fig. 6 Whole normal blood heated in vitro for seven minutes at $50^{\circ} \mathrm{C}$. $\times 2,700$. 
show the results of four and seven minutes' heating.

Since it is evident that not all cells were similarly affected by the heat treatment a partial fractionation according to cell ages was carried out. One fraction consisted of $9 \%$ of the youngest cells and the remainder was correspondingly enriched in older cells. These separate cell populations were heated, and Fig. 7 shows a typical preparation from the top layer. Figure 7 also shows more abnormal cells than a sample of whole blood heated to that temperature. The bottom fraction was less severely affected (Fig. 8). Nevertheless, even biconcave discs do not show a normal surface at higher magnifications (Fig. 9).

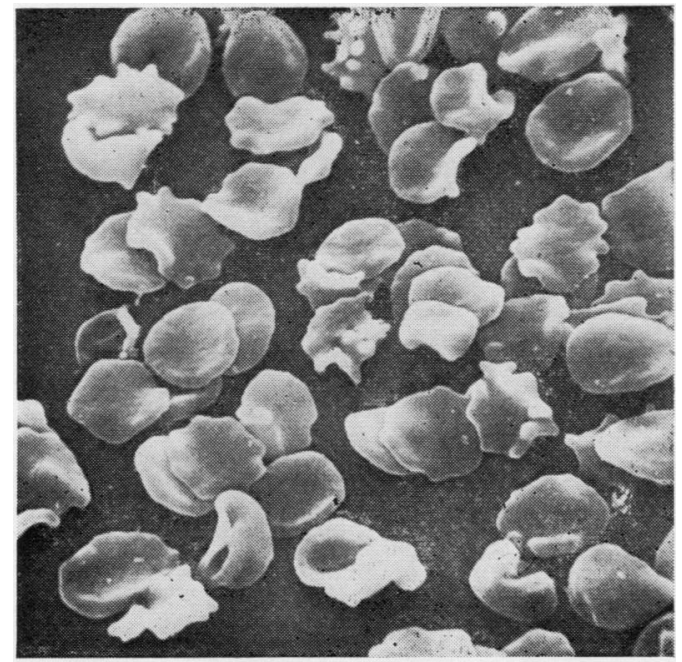

Fig. 7 Top $91 \%$ of whole normal blood heated in vitro for 10 minutes at $48^{\circ} \mathrm{C} . \times 2,300$.

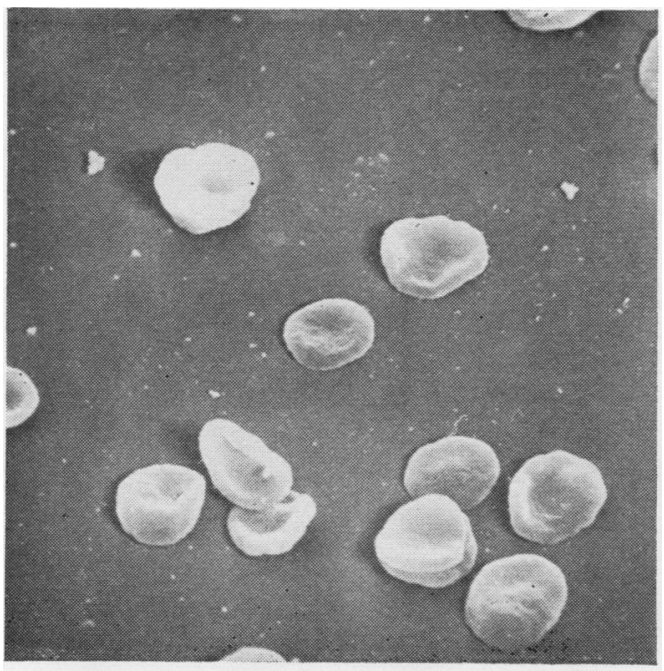

Fig. 8 Bottom $9 \%$ of whole normal blood heated in vitro for 10 minutes at $48^{\circ} \mathrm{C} . \times 2,320$.
The thickness of the cell has become more uni-을 form, the centre shows some pitting, and the whole structure suggests a degree of rigidity.®

\section{Discussion}

The photographic records obtained from the burned patient suggest two mechanisms of cellu- $\bar{\Phi}$ lar damage: first that of immediate severe damage, and secondly that of damage of trans $-\infty$ fused or patients' cells which initially remained $\overrightarrow{0}$ viable - a secondary response to the burning $\overrightarrow{-}$ injury. The existence of such a secondary event $\omega$ caused by the plasma of heat-damaged cells has been suggested by Baar and Topley (1962).

A blood sample of the patient investigated $\omega$ shows that two hours before death (Fig. 2) iv nearly all the cells were abnormal but different $N$ from the admission sample (Fig. 1). In spite of 0 the large blood transfusion the cells shown on Fig. 2 must be a mixed population of patient's and transfused cells, all, however, being affected $\stackrel{?}{?}$ similarly. This would suggest that some of the음 initially damaged patient's cells underwent $a$ 은 series of changes which possibly involved rever- $\vec{\theta}$ sion to normal cell morphology to reach the appearance recorded on Figure 2.

Support for this theory is lent by the apparent lack of the expected heat-dose effect as demonstrated on Fig. 3 when a blood sample had only been heated to $49^{\circ} \mathrm{C}$ instead of at $50^{\circ} \mathrm{C}$. Such an $\frac{2}{8}$ effect may be explicable in terms of differing $\varrho$ heat sensitivities of the various enzymes, depending 0 upon their direction towards the inside or outside $\exists$ of the membrane. Vansteveninck, Weed, and Rothstein (1965) have shown that only about $5 \%$ of the sulphydryl groups of the red cells are directed towards the outside of the membrane, $:$

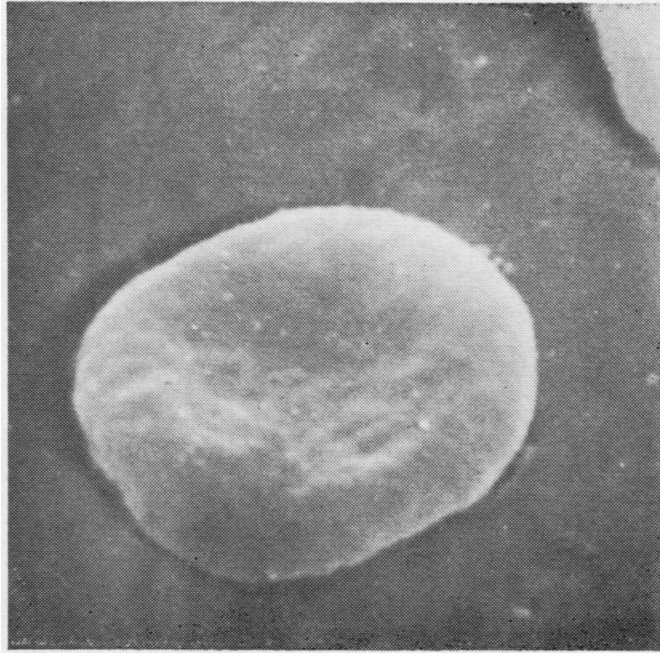

Fig. 9 Bottom $9 \%$ of whole normal blood heated in vitro for 10 minutes at $48^{\circ} \mathrm{C} . \times 11,600$. 
representing about $1,000,000$ groups per cell. The blocking of these sites by mercurial reagents led to an inhibition of glucose transport of about $90 \%$. This would suggest that a rate-limiting step, such as the hexokinase step, was involved. Since phosphoglycerate kinase is directed towards the lipid core of the membrane and glyceraldehyde phosphate dehydrogenase towards the interior of the cell as shown by Schrier (1966), their early involvement is unlikely.

Apparent reversibility of heat damage could also be explained in terms of the different thermal stability of the enzyme itself and an inhibitor substance. Such differences have been suggested for NAD pyrophosphatase by Swartz et al (1956).

As shown in Fig. 9, heat damage in erythrocytes was accompanied by the development of a general coarseness of the membrane and areas of pitting. An increase in granularity with cell age has been demonstrated with transmission electron microscopy by Danon and Marikovsky (1961). The same authors suggest that this is associated with the loss of membrane lipids and phospholipids. Since Salsbury and Clarke (1967) demonstrated coarse granularity following short-term treatment with saponin, it is attractive to suggest that at least one of the mechanisms responsible for the reduced viability of red cells in burned patients was due to lipid and phospholipid loss. Thermal damage might therefore cause premature aging of erythrocytes. A shortened life span of heat-damaged red cells was observed in rabbits by Karle (1969), who transfused cells heated in vitro to $41.5^{\circ} \mathrm{C}$, and in burned patients by Davies and Topley (1956).

Somewhat unexpectedly fractionation experiments showed the oldest cells to be less readily deformed than younger cells, although the former were coarsely granulated. A possible explanation could be the decreased flexibility of older cells which would therefore offer physical resistance to distortion-a similar explanation to that given by Ham, Sayre, Dunn, and Murphy (1968), who found that older cells had a decreased surface charge per unit area. This negative charge is largely due to sialic acid. Our own unpublished observations have shown that pre- treatment with sialidase offered a small degree of protection to thermal damage.

All findings therefore would suggest that heat accelerates the normal biological aging proces in red cells which survive thermal damage without showing immediate severe membrane damage

\section{References}

Baar, S. (1967). Experimental studies on the hydration of therm ally damaged erythrocytes. Brit. J. exp. Path., 48, 130-1340

Baar, S., and Topley, E. (1962). Observations on the alkali dê naturation of haemoglobin in burned rats. Brit. J. exp. Path., 43, 207-212.

Castle, W. B., and Daland, G. A. (1937). Susceptibility of erythrocytes to hypotonic hemolysis as a function de discoidal form. Amer. J. Physiol., 120, 371-383.

Clarke, J. A. (1968). Personal communication.

Danon, D., and Marikovsky. Y. (1964). Determination $\frac{\bigcap}{\delta \Phi}$ density distribution of red blood cells. J. Lab. clin. Med 64, 668-674.

Davies, J. W. L., and Topley, E. (1956). The disappearance of red cells in patients with burns. Clin. Sci., 15, 135-148. O

Ham, T. H., Sayre, R. W., Dunn, R. F., and Murphy, J. R. (1968) Physical properties of red cells as related to effects in vive II. Effect of thermal treatment on rigidity of red cells? stroma and the sickle cell. Blood, 32, 862-871.

Karle, H. (1969). Effect on red cells of a small rise in temperature in vitro studies. Brit. J. Haemat., 16, 409-419.

Kimber, R. J., and Lander, H. (1964). The effect of heat oक human red cell morphology, fragility and subsequen survival in vivo. J. Lab. clin. Med., 64, 922-933.

Lewis, S. M. (1967). Quoted in Salsbury and Clark (1967b).

Oatley, C. W., Nixon, W. C., and Pease, R. F. W. (1965). Scannin electron microscopy. Advance Electron. and Phys., 210 181-247.

Pfeiffer, H. (1905). Expərimentelle Beitraege zur Aetiologie de Verbrennungstodes. Virchows Arch. Path. Anat., 180 367-376.

Salsbury, A. J., and Clarke, J. A. (1967a). Surface ultramicrō scopy of human blood cells. 215, Nature (Lond.), 402-404. ڤ్

Salsbury, A. J., and Clarke, J. A. (1967b). New method for detect命 ing changes in the surface appearance of human red bloop cells. J. clin. Path., 20, 603-610.

Salsbury, A. J., and Clarke, J. A. (1968). Surface changes in reP blood cells undergoing agglutination. Rev. franç. Etud?

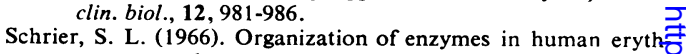
rocyte membranes. Amer. J. Physiol., 210, 139-145.

Schultze, M. (1865). Ein heizbarer Objektisch und seine Ver wendung bei Untersuchung des Blutes. Arch. mikrō Anat., 1, 1-42.

Shen, S.C., Ham, T. H., and Fleming, E. M. (1943). Studies on the destruction of red blood cells. III. Mechanism and com plications of haemoglobinuria in patients with thermab burns, spherocytosis and increased osmotic fragility of redB blood cells. New Engl. J. Med., 229, 701-720.

Swartz, M. N., Kaplan, N. O., and Frech, M. E. (1957). In Influence of Temperature on Biological Systems, edited by $\mathrm{F}$. Johnson, pp. 61-70. American Physiological Societyo Washington D.C.

Vansteveninck, J., Weed, R. I., and Rothstein, A. (1965). Local ization of erythrocyte membrane sulf hydryl groups essential for glucose transport. J. gen. Physiol., 48, 617-632. 